\title{
The awareness of blindness related to misuse of illicit liquor containing methanol: A community study
}

\author{
Indra Tri Mahayana, ${ }^{1, *}$ Tatang Talka Gani, ${ }^{1,2}$ Suhardjo Pawiroranu ${ }^{1,2}$ \\ ${ }^{1}$ Department of Ophthalmology, Faculty of Medicine, Public Health, and Nursing, \\ Universitas Gadjah Mada - Dr. Sardjito General Hospital, Yogyakarta, Indonesia \\ ${ }^{2}$ Dr. Yap Eye Hospital, Yogyakarta, Indonesia
}

\section{Submitted: 10 July 2018 Revised: 14 October 2018 Accepted: 6 November 2018}

\begin{abstract}
Methanol is a cheap organic solvent and additive in the production of illicit liquors. There are many recorded incidences in Indonesia regarding methanol intoxication induced visual loss. We aimed to investigate the level of awareness of liquor-containing methanol misuse in the community related to its hazard of visual loss. Participants were recruited from 3 primary health care units which represent the population of rural communities in Yogyakarta, Indonesia and then divided into two groups: drinkers (cases) and nondrinkers (control). The participants answered closed questions in a questionnaire about knowledges related to the misuse of illicit liquor. Forty participants (mean age: $39.8 \pm 13.4$ ) completed the questionnaires. There were $40 \%$ and $60 \%$ of participants who reside in the city and suburbs; their education levels were $2.5 \%, 12.5 \%, 30.0 \%, 35.0 \%$, and $7.5 \%$ for uneducated, elementary, junior, senior high school, and undergraduate, respectively. There were 6 drinker and 34 nondrinker participants (sex difference $p$ <0.001). Only 1 drinker and 7 nondrinkers answered correctly the questions regarding the ethanol based liquor. Fifty percent of drinkers and $32.4 \%$ of nondrinkers were aware that illicit liquors were most probably mixed with methanol. The drinkers were aware that liquor-containing methanol can cause sudden death $(33.3 \%)$ or sudden visual loss $(33.3 \%)$, while $55.8 \%$ nondrinker answered only sudden death. Participants' awareness levels regarding the content and the visual outcome of methanol-containing liquor remain low. From this pilot study, we confirmed the need to conduct further research with a larger sample size, followed by clear ethical considerations for blindness prevention.
\end{abstract}

KEYWORDS alcohol poisoning; methanol illicit liquor; vision loss; blindness prevention

\section{Introduction}

Several outbreaks of methyl alcohol poisoning have been reported recently. ${ }^{1-3}$ Methyl alcohol is a cheap and used as potent additive in the manufacture of illicit liquors. After ingested, methanol easily crosses all membranes and uniformly distributed to organs and tissues. ${ }^{4}$ In ophthalmology, it is closely associated with optic neuropathy, so called toxic optic neuropathy (TON) that produces hypoxia in highly metabolic tissue such as the optic nerves that is associated with retinal edema. ${ }^{5}$
Ingestion of liquor has been implicated in methanol toxicity as early as 1904, with the publication of Wood and Buller's report on 153 cases of blindness caused by methyl alcohol poisoning. ${ }^{6}$ A major catastrophe in 1951 documented 323 cases of methanol toxicity after intake of bootleg whiskey containing $35-40 \%$ methanol, later published as a comprehensive study by Benton and Calhoun in 1953. ${ }^{7}$ The most recent was a case in December 2000 of a Finnish man developing visual

*Corresponding author: Indra Tri Mahayana

Department of Ophthalmology, Faculty of Medicine, Public Health, and Nursing, Universitas Gadjah Mada - Dr. Sardjito General Hospital, Jl. Farmako, Sekip Utara, Yogyakarta 55281, Indonesia

E-mail: tri.mahayana@gmail.com 
deterioration resulting in monocular blindness (counting fingers in the left eye) following ingestion of locally produced coconut liquor in Indonesia. ${ }^{8} \mathrm{An}$ incident where 25 died from methanol poisoning in Indonesia also occurred in $2009 .^{9}$

There are many recorded incidences in Indonesia regarding visual loss induced by methanol intoxication. ${ }^{10}$ However, the consumption of methanol is still high and underrecorded. ${ }^{6}$ Besides government regulations, the community also has an important role in reducing methanol consumption thus decreasing the number of methanol intoxication induced blindness. ${ }^{8}$ One previous study in India showed a low awareness about visual loss in some rural communities followed by low awareness in health services, ${ }^{11}$ while there are still under recorded data due to the low level of blindness awareness in Indonesia.

This potentially fatal methanol poisoning may be underlined by low understanding of its hazards moreover regarding blindness. The basic knowledge regarding the hazard of methanol is needed to prevent the incidence of irreversible visual loss or worse. Therefore, we aimed to investigate the level of awareness of liquor-containing methanol misuse in the community related to its hazard of visual loss.

\section{Methods}

This research was a descriptive analytical study. Participants were recruited from 3 randomly assigned primary health care units in the province of Yogyakarta, Indonesia. The participants then answered closed questions in a questionnaire, asking their basic knowledge related to the misuse of liquor-containing methanol. The participants needed to answer a number of questions about the basic characteristics and the hazards of methanol liquor. Then we divided the participants into 2 groups, namely drinkers as case group and the nondrinker group as control, with the drinker group defined as participants who had experiences consuming illicit mixed liquor for more than three months. Nominal variables were inputted and analyzed by proportion test using Fisher exact test with $p<0.05$ considered as statistically significant.

\section{Results}

Forty participants (mean age: $39.8 \pm 13.4$ years old) completed the questionnaires. The basic characteristics (including residence area, and education levels) are shown in Table 1.

We also divided the participants into drinkers and nondrinkers, and analyzed their basic characteristics including the difference of their ocular symptoms (Table 2). Table 2 shows that there were significant differences in sex and ocular complaints $(p<0.001$ and $p$ $=0.026$, respectively), revealing that drinkers were all male and had specific ocular symptoms.

Table 3 shows that only 1 drinker and 7 nondrinker answered correctly regarding the ethanol based liquor, revealing that their prior knowledge regarding the content of the liquor was low. There were no significant differences between drinkers and nondrinkers.

Table 4 shows that $33.3 \%$ of drinkers were aware that illicit liquors were most probably mixed with methanol, while in the nondrinker group there were only $23.5 \%$. The drinkers were aware that liquor-contained methanol may cause either sudden death (33.3\%) or sudden visual loss (16.7\%), while $55.9 \%$ of nondrinkers answered only sudden death. The knowledge regarding the components of illicit liquor is still low and they were not aware

Table 1. Subject characteristics

\begin{tabular}{lc}
\hline Characteristics & \\
\hline Sex, $\mathrm{n}(\%)$ & $7(17.5)$ \\
$\quad$ Male & $33(82.5)$ \\
Female & $39.8 \pm 13.4$ \\
Age, mean $\pm \mathrm{SD}$ & \\
Reside, $\mathrm{n}(\%)$ & $16(40.0)$ \\
$\quad$ Urban & $24(60.0)$ \\
Suburban & \\
Education, $\mathrm{n}(\%)$ & $6(15.0)$ \\
Uneducated & $5(12.5)$ \\
Elementary school & $12(30.0)$ \\
Junior high school & $14(35.0)$ \\
Senior high school & $3(7.5)$ \\
$\quad$ Undergraduate &
\end{tabular}


Table 2. The differences between chronic alcohol drinkers and nondrinkers

\begin{tabular}{|c|c|c|c|}
\hline & Drinker $(n=6)$ & Nondrinker $(n=34)$ & $p$ \\
\hline \multicolumn{4}{|l|}{ Sex, n (\%) } \\
\hline Male & $5(83.3)$ & $3(8.8)$ & $<0.001$ \\
\hline Female & $1(16.7)$ & $31(91.2)$ & \\
\hline Age, mean $\pm S D$ & $40.3 \pm 14.4$ & $39.7 \pm 13.4$ & 0.917 \\
\hline \multicolumn{4}{|l|}{ Residence, n (\%) } \\
\hline Urban & $4(66.7)$ & $12(35.3)$ & 0.148 \\
\hline Suburban & $2(33.3)$ & $22(64.7)$ & \\
\hline \multicolumn{4}{|l|}{ Education, n (\%) } \\
\hline Uneducated & $0(0.0)$ & $6(17.6)$ & 0.633 \\
\hline Elementary School & $0(0.0)$ & $5(14.7)$ & \\
\hline Junior High School & $3(50.0)$ & $9(26.5)$ & \\
\hline Senior High School & $3(50.0)$ & $11(32.4)$ & \\
\hline Undergraduate & $0(0.0)$ & $3(8.8)$ & \\
\hline \multicolumn{4}{|l|}{ Ocular complains, n (\%) } \\
\hline Blurred vision & $2(33.3)$ & $16(47.1)$ & 0.026 \\
\hline Ocular pain & 1 (16.7) & $4(11.8)$ & \\
\hline Dry eyes & $0(0.0)$ & $1(2.9)$ & \\
\hline Total visual field loss & $1(16.7)$ & $0(0.0)$ & \\
\hline Partial visual field loss & $2(33.3)$ & $0(0.0)$ & \\
\hline Combined visual field loss & $0(0.0)$ & $1(2.9)$ & \\
\hline No complain & $0(0.0)$ & $12(35.3)$ & \\
\hline
\end{tabular}

The differences were analyzed using Fisher exact test, $p<0.05$ as significant.

Table 3. The difference of basic knowledge regarding alcohol and methanol between drinkers and nondrinkers (total answers)

\begin{tabular}{lcccc}
\hline Question & Number of correct answer & Drinker $(\mathrm{n}=6)$ & Nondrinker $(\mathrm{n}=\mathbf{3 4})$ & $\boldsymbol{p}$ \\
\hline Ethanol, $\mathrm{n}(\%)$ & $8(20.0)$ & $1(16.7)$ & $7(20.6)$ & 0.869 \\
Methanol, $\mathrm{n}(\%)$ & $14(35.0)$ & $3(50.0)$ & $11(32.4)$ & 0.583 \\
\hline
\end{tabular}

The differences were analyzed using Fisher exact test; $p<0.05$ as significant.

that it may contain methanol. Otherwise, there were no significant differences between drinkers and nondrinkers.

\section{Discussion}

Our study mainly focused on community awareness about basic knowledge of illicit liquor substance and its side effects. We found that the knowledge regarding the components of illicit liquor is still low and many were not aware that it may contain methanol. We also found that the chronic drinkers had specific ocular symptoms. This result was significant due to our subjects in the drinker group were obtained from patients with TON. Methanol toxicity is a common problem among individuals of the lower socioeconomic classes in developing countries. Methanol toxicity usually occurs from intentional overdose or accidental ingestion and results in metabolic acidosis, neurologic sequelae, and even death. ${ }^{12}$ Specifically, the toxicity is a combined effect of the metabolic acidosis and an intrinsic toxicity of the formate anion. ${ }^{13}$

Methanol poisoning is a medical emergency. It will be a permanent phenomenon in human communities and requires special attention. The severe damage of visual function is devastating to 
Table 4. The difference of basic knowledge regarding alcohol and methanol between drinkers and nondrinkers (per question item)

\begin{tabular}{lccc}
\hline Questions & $\begin{array}{c}\text { Drinker } \\
(\mathbf{n}=6)\end{array}$ & $\begin{array}{c}\text { Nondrinker } \\
(\mathbf{n}=\mathbf{3 4})\end{array}$ & $\boldsymbol{p}$ \\
\hline The component of alcohol, $\mathrm{n}(\%)$ & & & \\
$\quad$ Ethanol & $1(16.7)$ & $7(20.6)$ & 0.948 \\
$\quad$ Methanol & $1(16.7)$ & $9(26.5)$ & \\
Others & $2(33.3)$ & $10(29.4)$ & \\
$\quad$ No Idea & $1(16.7)$ & $4(11.8)$ & \\
The component of Illicit mixed liquor, $\mathrm{n}(\%)$ & & & \\
$\quad$ Ethanol & $1(16.7)$ & $8(23.5)$ & 0.691 \\
Methanol & $2(33.3)$ & $8(23.5)$ & \\
Others & $1(16.7)$ & $8(23.5)$ & \\
$\quad$ No Idea & $2(33.3)$ & $6(17.6)$ & \\
Adverse effects of methanol mixed liquor, $\mathrm{n}(\%)$ & & & \\
$\quad$ Sudden death & $2(33.3)$ & $19(55.9)$ & 0.781 \\
Sudden vision loss & $1(16.7)$ & $2(5.9)$ & \\
Internal organ damage & $2(33.3)$ & $8(23.5)$ & \\
$\quad$ Combination & $1(16.7)$ & $4(11.8)$ \\
$\quad$ Others & $0(0.0)$ & $1(2.9)$ & \\
\hline
\end{tabular}

The differences were analyzed using Fisher exact test; $p<0.05$ as significant.

a person's life. This condition could not happen if the misuse of liquor were regulated well by the government, yet now it is still considered as a major problem in Indonesia. ${ }^{14}$ There are many factors associated with liquor misuse, but the important one is the socioeconomic factor. Drinkers tend to use illicit liquor to warm their bodies, either to be acknowledged by others, or as an escapement when they have problems. ${ }^{15}$ There are two factors associated with liquor misuse such as internal factors from the individual characteristics (genetics, psychological stress, personality disorder, and issues related to religion) and external factors (socioeconomic factors, background, and social control issues, such as peer pressure). ${ }^{16}$

The negative consequences of illicit liquor misuse has driven the need for a multi-component intervention which can beaccepted by communities. In Australia, there was a randomized controlled trial study in 20 communities called Alcohol Action in Rural Communities (AARC) project that reported some significant impact. ${ }^{17}$ As a result, it was found that the increase of community awareness of blindness related to liquor misuse was related to multicomponent interventions, such as community engagement and counseling.

From our result, we can conclude that the level of awareness regarding substances and impact of illicit liquor still does not meet expectations. Our data could be used in terms of basic knowledge of awareness in rural areas and could be implemented in paramedical, rehabilitation, and primary health care centers. Our study limitations include: there were inadequate samples for case group and there was no validation in our self-developed questionnaires. We confirmed the need to conduct further interventional community studies such as counseling and evaluating the level of awareness continuously and prospectively.

\section{Conclusion}

Participants' awareness levels regarding the content and the visual outcome of consuming methanol-containing liquor remain low. Knowledge and understanding regarding the hazards are important to prevent the incidence of blindness related to misuse of this illicit liquor. From this pilot study, we recommend conducting further research with larger sample sizes, followed by clear ethical 
considerations for blindness prevention.

\section{Acknowledgments}

There are no conflicts of interest to disclose, this research was made purely for developing better health community.

\section{References}

1. Das A, Siddique A, Haque M, Lopa I. Acute blindness following methanol poisoning. J Bangladesh Coll Phys Surg. 2014;31:232-4.

2. Surhio SA, Memon S, Memon M, Nizamani NB, Talpur KI. Alcohol related toxic optic neuropathy case series. Ophthalmol Pak. 2013;29:173.

3. Zakharov S, Nurieva O, Navratil T, Diblik P, Kuthan P, Pelclova D. Acute methanol poisonings: Folates administration and visual sequelae. J Appl Biomed. 2014;12:309-16.

4. Wang MY, Sadun AA, Chan JW. Optic Nerve Disorders. 2nd ed. New York: Springer; 2014. Chapter: Nutritional and toxic optic neuropathies. p. 177-207.

5. Grzybowski A, Zülsdorff $M$, Wilhelm $H$, Tonagel F. Toxic optic neuropathies: An updated review. Acta Ophthalmol. 2015;93:402-10.

6. Hayreh MS, Hayreh SS, Baumbach GI, Cancilla P, Martin-Amat G, Tephly TR, et al. Methyl alcohol poisoning III. Ocular toxicity. Arch Ophthalmol. 1977;95(10):1851-58.

7. Benton CD, Calhoun FP. The ocular effects of methyl alcohol poisoning: Report of a catastrophe involving 320 persons. Am J Ophthalmol. 1953;36(12):1679-85.

8. Halavaara J, Valanne L, Setälä K. Neuroimaging supports the clinical diagnosis of methanol poisoning. Neuroradiology. 2002;44(11):924928.

9. $\mathrm{BBC}$ News. More alcohol deaths in Indonesia [Internet]. UK: BBC News; 2009. [updated 2009; cited 20 October 2018]. Available from: http:// News.Bbc.Co.Uk/2/Hi/Asia-Pacific/8079531. Stm

10. Yunita DR. Hubungan konsumsi minuman beralkohol dengan tajam penglihatan pada peminum alkohol usia 15-39 tahun di Kota
Malang [bachelor's thesis]. Malang: Universitas Muhammadiah Malang. Institutional Repository; 2014.

11. Fletcher A. Low uptake of eye services in rural India. Arch Ophthalmo. 1999;117(10):1393.

12. MustafaS, Pandit L. 2014. Approach to diagnosis and management of optic neuropathy. Neurol India. 2014;62:599.

13. Zakharov S, Nurieva O, Kotikova K, Urban P, Navratil T, Pelclova D. Factors predicting optic nerve axonal degeneration after methanolinduced acute optic neuropathy: A 2-year prospective study in 54 patients. Monatsh Chem. 2016;147:251-61.

14. Yamani N. Dampak perilaku penggunaan minuman keras di kalangan remaja di Kota Surakarta [bachelor's thesis]. Surakarta: Universitas Muhammadiyah Surakarta ETD-db; 2009.

15. Parry C, Patra J, Rehm J. Alcohol consumption and non-communicable diseases: Epidemiology and policy implications. Addiction. 2011;106(10):1718-1724.

16. Rehm J, Baliunas D, Borges G, Graham K, Irving $\mathrm{H}$, Kehoe $\mathrm{T}$, et al. The relation between different dimensions of alcohol consumption and burden of disease: An overview. Addiction. 2010;105(5):817-843.

17. Navarro H, Shakeshaft A, Doran C, Petrie D. Does increasing community and liquor licensees' awareness, police activity, and feedback reduce alcohol-related violent crime? A benefit-cost analysis. Int J Environ Res Public Health. 2013; 10(11):5490-506. 